\title{
Expression of calbindin-D28k and its regulation by estrogen in the human endometrium during the menstrual cycle
}

\author{
Hyun Yang ${ }^{1 \dagger}$, Tae-Hee Kim ${ }^{2 \dagger}$, Hae-Hyeog Lee ${ }^{2}$, Kyung-Chul Choi ${ }^{1}$, Yeon-pyo Hong ${ }^{3}$, Peter CK Leung ${ }^{4}$, \\ Eui-Bae Jeung ${ }^{1^{*}}$
}

\begin{abstract}
Human endometrium resists embryo implantation except during the 'window of receptivity'. A change in endometrial gene expression is required for the development of receptivity. Uterine calbindin-D28k (CaBP-28k) is involved in the regulation of endometrial receptivity by intracellular Ca2+. Currently, this protein is known to be mainly expressed in brain, kidneys, and pancreas, but potential role(s) of CaBP-28k in the human uterus during the menstrual cycle remain to be clarified. Thus, in this study we demonstrated the expression of CaBP-28k in the human endometrium in distinct menstrual phases. During the human menstrual cycle, uterine expression levels of CaBP-28k mRNA and protein increased in the proliferative phase and fluctuated in these tissues, compared with that observed in other phases. We assessed the effects of two sex-steroid hormones, 17beta-estradiol (E2) and progesterone (P4), on the expression of CaBP-28k in Ishikawa cells. A significant increase in the expression of CaBP28k mRNA was observed at the concentrations of E2 (10(-9 to -7) M). In addition, spatial expression of CaBP-28k protein was detected by immunohistochemistry. CaBP-28k was abundantly localized in the cytoplasm of the luminal and glandular epithelial cells during the proliferative phases (early-, mid-, late-) and early-secretory phase of menstrual cycle. Taken together, these results indicate that CaBP-28k, a uterine calcium binding protein, is abundantly expressed in the human endometrium, suggesting that uterine expression of CaBP-28k may be involved in reproductive function during the human menstrual cycle.
\end{abstract}

\section{Background}

Intracellular calcium binding proteins (calbindins) are critical for regulating the availability of calcium ions $\left(\mathrm{Ca}^{2+}\right)$ within cells. There are two types of cytosolic calbindins, calbindin- $\mathrm{D}_{9 \mathrm{k}}(\mathrm{CaBP}-9 \mathrm{k})$ and calbindin- $\mathrm{D}_{28 \mathrm{k}}$ (CaBP-28k), which are cytosolic proteins differentially regulated by steroid hormones in the uterus $[1,2]$. In addition to its traditional role in extracellular calcium homeostasis [3], vitamin D influences a broad range of cellular events, ranging from oncogene expression [4] and immunoregulation [5] to cellular differentiation $[6,7]$ and intracellular calcium metabolism [8]. Previous studies have documented that vitamin D deficiency

\footnotetext{
*Correspondence: ebjeung@chungbuk.ac.kr

+ Contributed equally

'Laboratory of Veterinary Biochemistry and Molecular Biology, College of Veterinary Medicine, Chungbuk National University, Cheongju, Chungbuk 361-763, Republic of Korea

Full list of author information is available at the end of the article
}

decreases fertility in female rats [9-11], and vitamin D-dependent calcium-binding proteins were discovered in reproductive tissues: $\mathrm{CaBP}-9 \mathrm{k}$ in the uterus of rats [12-14], and the larger CaBP-28k in the uterus of domestic fowl $[15,16]$.

The expression of CaBP-9k and CaBP-28k in reproductive tissues is affected by steroid hormones $[12,14,15,17]$. For example, the expression of CaBP-9k mRNA in the mouse uterus was significantly increased by treatment with $\mathrm{P} 4$ and E2 plus P4, but not by E2 alone $[18,19]$. Conversely, rat uterine CaBP-D9k mRNA was induced only by E2 [20]. In hens, uterine expression of the larger calbindin- $\mathrm{D}_{28 \mathrm{k}}$ increased by the addition of testosterone [15].

Embryo implantation is a complex process involving interactions between the blastocyst and the uterus. A successful implantation requires the development of the blastocyst stage, its escape from the zonapellucida, 
and the establishment of a receptive uterus [21]. The primate endometrium undergoes certain hormonedependent changes during a particular time window within the preimplantation phase that prepares it to receive the growing blastocyst [22-24]. A complex interaction between effectors, including steroid hormones, growth factors, and cytokines, regulates development of the "receptivity" state of the uterine epithelium [25-28].

The action of calcium ions in female reproductive organs has also been widely studied for several decades. It has been suggested that calcium ions are involved in uterine smooth muscle contraction and fetal implantation $[1,29,30]$. Additionally, the balance of calcium ions during uterine contraction and relaxation is extremely important throughout pregnancy and during labor. However, the mechanism of regulation of calcium levels in uterine tissue remains largely unknown. In the present model of calcium flux in uterine tissue, calcium ions flow into the cytoplasm through ion transport proteins, exchangers, or calcium-binding proteins, i.e., CaBP-9k and CaBP-28k. Furthermore, the mechanism and regulation of calcium-related genes in the uterus are not fully characterized, and it is likely that the regulation of calcium ion flux is complex and involves a diverse set of proteins. For instance, implantation in CaBP-9k knockout mice appears to occur normally, while CaBP-9k/CaBP-28k double knockout mice experience failed embryo implantation [28]. These results demonstrate that the expression patterns of CaBP-28k may be involved in reproductive function and fetal implantation during the menstrual cycle in female mice.

In our previous studies, the expression of uterine CaBP-28k mRNA and protein in mice during the estrus cycle is regulated by sex-steroid hormones [18,31]. However, the role of CaBP-28k in the human uterus has yet to be fully characterized. It is likely that CaBP-28k is functionally important in female reproductive organs. We examined the effect of steroid hormones E2 and P4 on the expression of CaBP-28k in the human endometrial tissues during the different stages of the menstrual cycle and in Ishikawa endometrial cancer cells. In addition, we also examined the intracellular localization of uterine CaBP-28k in human female endometrial tissue.

\section{Methods \\ Materials}

$17 \beta$-Estradiol (E2), progesterone (P4), and mifepristone (RU486) were obtained from Sigma-Aldrich Corporation (St. Louis, MO). ICI 182780 was purchased from TOCRIS (Avonmouth, UK).

\section{Endometrial tissue}

Human endometrial tissues were collected by curettage from women (the ages of 28-45 years) undergoing hysteroscopy for investigation of tubal p"36atency or tubal ligation. Endometrial tissues were classified according to the most recent menstrual period, and histology was performed according to the criteria of Noyes et al. [32]. Approval was given by the Human Ethics Committee at SCH Medical Center (Bucheon, Korea), and signed consent was obtained in every case. Human uterine finally classified samples (total $n=42$ ) were divided into seven groups ( $\mathrm{n}=6$ in each period): menstrual, proliferative (early, mid, late), and secretory phase (early, mid, late). Endometrial tissues were transported to the laboratory in buffered neutral formalin $(10 \%)$ on ice. Tissues were then quickly frozen in liquid nitrogen and stored at $-70^{\circ} \mathrm{C}$ until further use.

\section{Cell culture and treatment}

Ishikawa cells were obtained from Sigma-Aldrich (St. Louis, MO). The cells were grown as monolayer cultures in Dulbecco's Modified Eagle Medium (DMEM; Gibco BRL, Grand Island, NY), supplemented with $10 \%$ fetal bovine serum (FBS; Gibco BRL), $100 \mathrm{IU} / \mathrm{mL}$ penicillin, and $100 \mu \mathrm{g} / \mathrm{mL}$ streptomycin (Gibco BRL) at $37^{\circ} \mathrm{C}$ in a humidified atmosphere of $95 \% \mathrm{O}_{2}$ and $5 \% \mathrm{CO}_{2}$. To challenge Ishikawa cells to $\mathrm{E} 2$ and $\mathrm{P} 4$, the cells were plated and grown to $70-80 \%$ confluence in six-well plastic tissue culture dishes (NUNCTM, Roskilde, Denmark). In order to ensure depletion of steroid hormones and growth factors in the cells, the growth medium was replaced with starvation media containing phenol redfree DMEM with $5 \%$ dextran-coated charcoal-stripped FBS, $100 \mathrm{IU} / \mathrm{mL}$ penicillin, and $100 \mu \mathrm{g} / \mathrm{mL}$ streptomycin, as described previously [33]. The Ishikawa cells were maintained on starvation media for 3 days before exposure to three concentrations of E2 $\left(10^{-9} \mathrm{M}, 10^{-8} \mathrm{M}\right.$, and $\left.10^{-7} \mathrm{M}\right)$ and $\mathrm{P} 4\left(10^{-7} \mathrm{M}, 10^{-6} \mathrm{M}\right.$, and $\left.10^{-5} \mathrm{M}\right)$. To further investigate whether ER or PR is involved in the expression of CaBP-28k protein, the cells were pretreated with ICI $182780\left(10^{-6} \mathrm{M}\right)$ or mifepristone $\left(10^{-6}\right.$ M) for $60 \mathrm{~min}$ prior to the treatment with E2 $\left(10^{-8} \mathrm{M}\right)$ or P4 $\left(10^{-6} \mathrm{M}\right)$. Each chemical was dissolved in DMSO and added to the starvation media with the final DMSO concentration being $0.1 \%$. DMSO alone was used as a negative control. Ishikawa cells were harvested $48 \mathrm{~h}$ after treatment with E2 or P4 to measure mRNA levels, and whole cells were harvested for mRNA and Western blot analyses. All experiments were performed in triplicate (group $\mathrm{n}=3$ ).

\section{Total RNA extraction and quantitative real-time PCR}

Endometrial tissues were transported, rapidly excised, and washed in cold, sterile $\mathrm{NaCl}(0.9 \%)$. Total RNA was prepared with Trizol reagent (Invitrogen, Carlsbad, CA), and the concentration of RNA was determined by absorbance at $260 \mathrm{~nm}$. Total RNA $(1 \mu \mathrm{g})$ was reverse 
transcribed into first-strand cDNAs using Moloney murine leukemia virus (MMLV) reverse-transcriptase (Invitrogen, Carlsbad, CA) and random primers (9-mers; Takara Bio Inc., Otsu, Shiga, Japan). Two microliters of cDNA template was added to $10 \mu \mathrm{L}$ of $2 \times$ SYBR Premix Ex Taq (TaKaRa Bio) and 10 pmol of each specific primer. The reactions were carried out for 40 cycles according to the following parameters: denaturation at $95^{\circ} \mathrm{C}$ for $30 \mathrm{~s}$, annealing at $58^{\circ} \mathrm{C}$ for $30 \mathrm{~s}$, and extension at $72^{\circ} \mathrm{C}$ for $45 \mathrm{~s}$. The oligonucleotide primers for CaBP28k were 5' - AGT GGT TAC CTG GAA GGA AAG G -3' (sense) and 5'- AGC AGG AAA TTC TCT TCT GTG G -3' (antisense). The primers for GAPDH were 5'- GGT GTG AAC CAT GAG AAG TAT GAC -3' (sense) and 5'- AGT AGA GGC AGG GAT GAT GTT CT -3' (antisense). Fluorescence intensity was measured at the end of the extension phase of each cycle. The threshold value for the fluorescence intensity of all samples was set manually. The reaction cycle at which PCR products exceeded this fluorescence intensity threshold was identified as the threshold cycle [34] in the exponential phase of the PCR amplification. The expression of calbindin- $D_{28 k}$ was quantified against that of GAPDH. Relative quantification was based on the comparison of CT [cycle threshold] at a constant fluorescent intensity. The amount of transcript is inversely related to the magnitude of observed CT, and for every twofold dilution in the transcript, CT is expected to increase by one. Relative expression was calculated using the equation $R=2^{-[\Delta C T \text { sample }-\Delta C T \text { control] }}$ [26]. To determine a normalized arbitrary value for each gene, every obtained value was normalized to that of GAPDH.

\section{Reverse transcription polymerase chain reaction (RT-PCR)}

Total RNA was extracted and cDNA synthesized as described in the preceding paragraph. RT-PCR was performed as described by [35]. Denaturation was performed at $95^{\circ} \mathrm{C}$ for $30 \mathrm{~s}$, annealing at $58^{\circ} \mathrm{C}$ for $30 \mathrm{~s}$ (for CaBP-28k) or at $55^{\circ} \mathrm{C}$ for $30 \mathrm{~s}$ (for GAPDH), and extension at $72^{\circ} \mathrm{C}$ for $30 \mathrm{~s}$. Cycling kinetics were performed using 20, 25, and 30 cycles, to ensure linearity of PCR product detection, and the final PCR condition was 30 cycles for CaBP-28k or 25 cycles for GAPDH. Eight microliters of PCR products was loaded on $2 \%$ agarose gel and stained with ethidium bromide following electrophoresis. The intensity of the PCR bands was determined directly by scanning the agarose gel and was analyzed using the molecular analysis program version 4.5.1 (Gel Doc 1000, Bio-Rad, Hercules, CA).

\section{Western blot analysis}

Endometrial tissues were transported, rapidly excised, and washed in cold sterile $0.9 \% \mathrm{NaCl}$ solution. Protein was extracted with Pro-prep (iNtRON Bio Inc, Sungnam, Kyungki-Do, Korea) according to the manufacturer's instructions. The cells were harvested, washed two times with ice-cold PBS, and then resuspended in $20 \mathrm{mM}$ Tris$\mathrm{HCl}$ buffer ( $\mathrm{pH}$ 6.4) containing protease inhibitors $(0.1$ $\mathrm{mM}$ phenylmethylsulfonyl fluoride, $5 \mu \mathrm{g} / \mathrm{mL}$ pepstatin $\mathrm{A}$, and $1 \mu \mathrm{g} / \mathrm{mL}$ chymostatin). Whole cell lysate was prepared using 20 strokes of a Dounce homogenizer, followed by centrifugation at $13,000 \mathrm{~g}$ for $20 \mathrm{~min}$ at $4^{\circ} \mathrm{C}$. Proteins (70 $\mu$ g per lane) were separated on a $10 \%$ SDSpolyacrylamide gel electrophoresis (PAGE) gel and transferred to a polyvinylidene fluoride transfer membrane (Perkin Elmer Co., Wellesley, MA) in a TransBlot Cell (TE-22, Hoefer Inc, San Francisco, CA) according to the manufacturer's protocol. The resulting blot was blocked in TBS-T (Tris-Buffered Saline Tween-20) containing 5\% skim milk for $60 \mathrm{~min}$ and then incubated with primary antibody: CaBP-28k (goat-polyclonal, 1:500, Santa Cruz, CA, USA) or GAPDH (mouse-monoclonal, 1:2000, Assay Design Inc, Ann Abor, MI). After being washed in buffer, the membranes were incubated with the appropriate horseradish peroxidase-conjugated secondary antibodies (anti-goat, 1:2000 or anti-mouse, 1:5000, Santa Cruz, CA) for $1 \mathrm{~h}$ at room temperature (RT). After being washed, the blots were developed by incubation in ECL chemiluminescence reagent (Santa Cruz, CA) and subsequently exposed to Biomax ${ }^{\mathrm{TM}}$ Light film (Kodak) for 1-5 min. Signal specificity was confirmed by blotting in the absence of primary antibody, and bands were normalized to GAPDH-immunoreactive bands visualized in the same membrane after stripping. Density measurements for each band were performed with NIH ImageJ software. Background samples from an area near each lane were subtracted from each band to obtain mean band density.

\section{Immunohistochemical staining}

Localization of CaBP-28k protein was examined by immunohistochemistry. Endometrial tissues were embedded in paraffin, before sections $(5 \mu \mathrm{m})$ were deparaffinized in xylene and hydrated in descending grades of ethanol. Endogenous peroxidase activity was blocked with 3\% hydrogen peroxide in TBS-T for $30 \mathrm{~min}$. Nonspecific reactions were blocked by incubating the sections in $10 \%$ normal goat serum for $2 \mathrm{~h}$ at $\mathrm{RT}$. The sections were subsequently incubated at RT for $4 \mathrm{~h}$ with a polyclonal goat antibody directed against CaBP-28k (diluted 1:300; Santa Cruz, CA, USA) dissolved in $10 \%$ normal goat serum. After being washed with TBS-T, the sections were incubated with a biotinylated secondary antibody (goat IgG, Vector Laboratories, Burlingame, CA) for $30 \mathrm{~min}$ at $37^{\circ} \mathrm{C}$ and then incubated with $\mathrm{ABC}$-Elite for $30 \mathrm{~min}$ at $37^{\circ} \mathrm{C}$. Diaminobenzidine (DAB; Sigma) was used as a chromogen, and the 
sections were counterstained with hematoxylin, followed by mounting in Canada balsam.

\section{Data analysis}

Data were presented as the means \pm SEM and analyzed by one-way analysis of variance (ANOVA), followed by Tukey's multiple comparison test. Statistical analysis was performed using Prism Graph Pad (v4.0; GraphPad Software Inc., San Diego, CA, USA). $P<0.05$ was considered to be statistically significant.

\section{Results}

Pattern of endometrial calbindin- $\mathrm{D}_{28 \mathrm{k}}$ expression

To investigate the expression of endometrial CaBP-28k during the menstrual cycle, we divided the endometrial tissues into seven groups [menstrual phase, proliferative phase (early, mid, late), and secretory phase (early, mid, late) according to the most recent menstrual period, and histology according to the criteria of Noyes et al. [32]. In normalization to GAPDH, CaBP-28k mRNA levels in the proliferative phase (early, mid, late) and secretory phase (early) were induced up to 1.5-, 2.5-, 2.5-, and 2.0-fold higher than in the menstrual phase, respectively (Figure 1). This induced expression of CaBP-28k was significantly decreased in secretory phases (early, mid, and late) compared to that in proliferative phases (mid and late phases). In parallel with mRNA levels, the protein levels of CaBP-28k were higher in

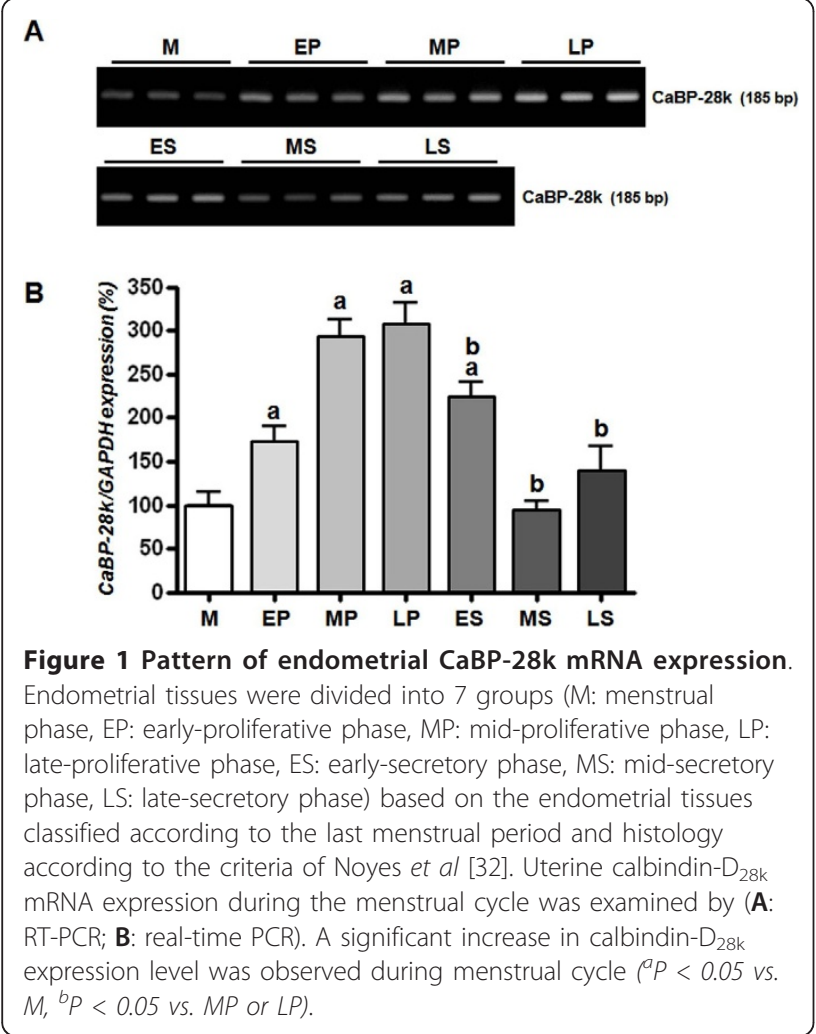

the proliferative phase (early-, mid-, late-) than in the other phases (Figure 2). This induced protein level of CaBP-9k was also reduced in secretory phases compared to that of proliferative phases as shown in Figure 2.

\section{Effect of sex-steroid hormone E2 and P4 on regulation of} calbindin- $D_{28 k}$ expression in Ishikawa cells

We assessed the effects of sex-steroid hormones E2 and $\mathrm{P} 4$ on the regulation of CaBP-28k in Ishikawa cells. A panel of chemicals comprising E2 and P4 were applied to Ishikawa cells at increasing concentrations (E2: $10^{-9} \mathrm{M}$ to $10^{-7} \mathrm{M}$, and P4: $10^{-7} \mathrm{M}$ to $10^{-5} \mathrm{M}$ ). As shown in Figure 3, a significant increase in the expression of CaBP-28k mRNA was observed in the cells treated with E2 $\left(10^{-9} \mathrm{M}\right.$ to $\left.10^{-7} \mathrm{M}\right)$. Compared to vehicle (negative) controls, CaBP-28k mRNA levels were increased up to 2.0- and 2.5-fold, respectively (Figure 3). Also, we elucidated the involvement of the estrogen receptor (ER) in the E2-induced CaBP-28k increase in Ishikawa cells by treating the cells with an ER antagonist or PR antagonist (ICI and mifepristone, respectively) for 60 min prior to the treatment with E2 $\left(10^{-8} \mathrm{M}\right)$ or P4 $\left(10^{-6} \mathrm{M}\right)$. Pretreatment with an ER antagonist completely reversed the E2-induced increase in CaBP-28k expression (Figure 4), suggesting that ERs are involved in the E2-mediated regulation of CaBP-28k expression in Ishikawa cells. Furthermore, after pretreatment with a PR antagonist, the P4-induced CaBP-28k expression was not changed, indicating that PRs are not involved in the expression of CaBP-28k protein in Ishikawa cells.
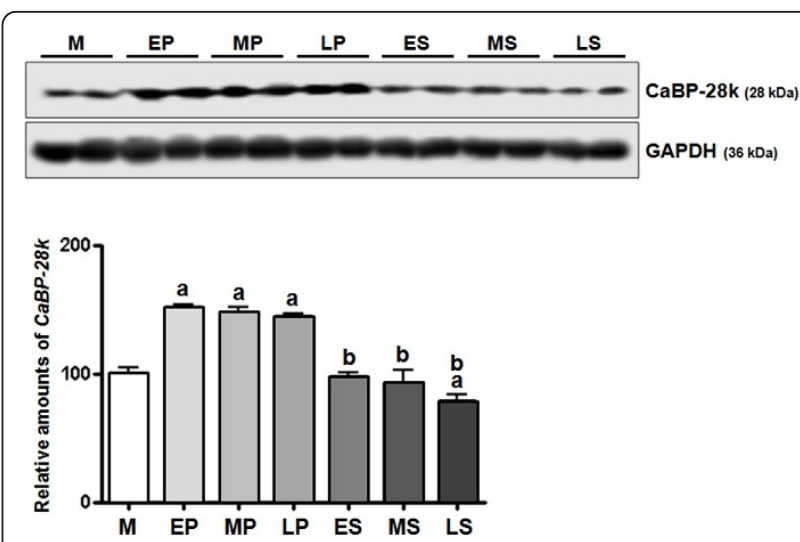

Figure 2 Pattern of endometrial CaBP-28k protein expression Endometrial tissues were divided into 7 groups (M: menstrual phase, EP: early-proliferative phase, MP: mid-proliferative phase, LP: late-proliferative phase, ES: early-secretory phase, MS: mid-secretory phase, LS: late-secretory phase) based on the endometrial tissues classified according to the last menstrual period and histology according to the criteria of Noyes et al [32]. Uterine CaBP-28k protein expression during the menstrual cycle was examined by WESTERN BLOT. A significant increase in calbindin- $D_{28 \mathrm{k}}$ expression level was observed during menstrual cycle ${ }^{a} P<0.05$ vs. $M^{b}{ }^{b} P<$ 0.05 vs. MP or $(P)$. 


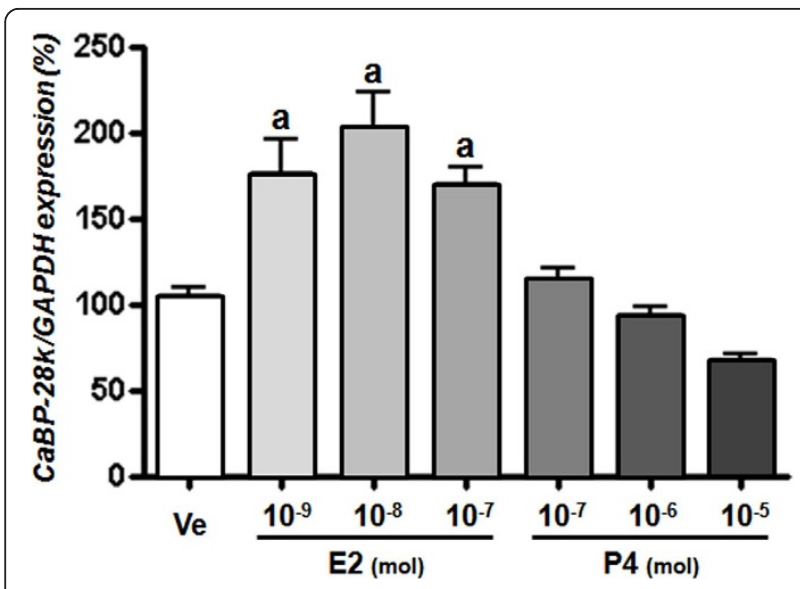

Figure 3 Effect of sex-steroid hormone E2 and P4 on regulation of CaBP-28k mRNA expression. The cells were treated with only DMSO (Ve, negative control), E2 (10 $0^{-9}$ to $\left.{ }^{-7} \mathrm{~mol}\right), \mathrm{P} 4\left(10^{-7}\right.$ to ${ }^{-5}$ mol) for 2 days. Graphs represent the analysis of real-time PCR data. ${ }^{a} P<0.05$ indicate a significant difference in $\mathrm{CaBP}-28 \mathrm{~K}$ expression level compared to a negative control.

Localization of calbindin- $D_{28 k}$ expression in human endometrial tissue

To assess the spatial pattern of expression of CaBP-28k in the endometrial tissue, we analyzed tissue sections at different stages of the menstrual phases (early-, mid-, late-proliferative phase or secretory phase) by immunohistochemistry using an anti-CaBP-28k antibody.

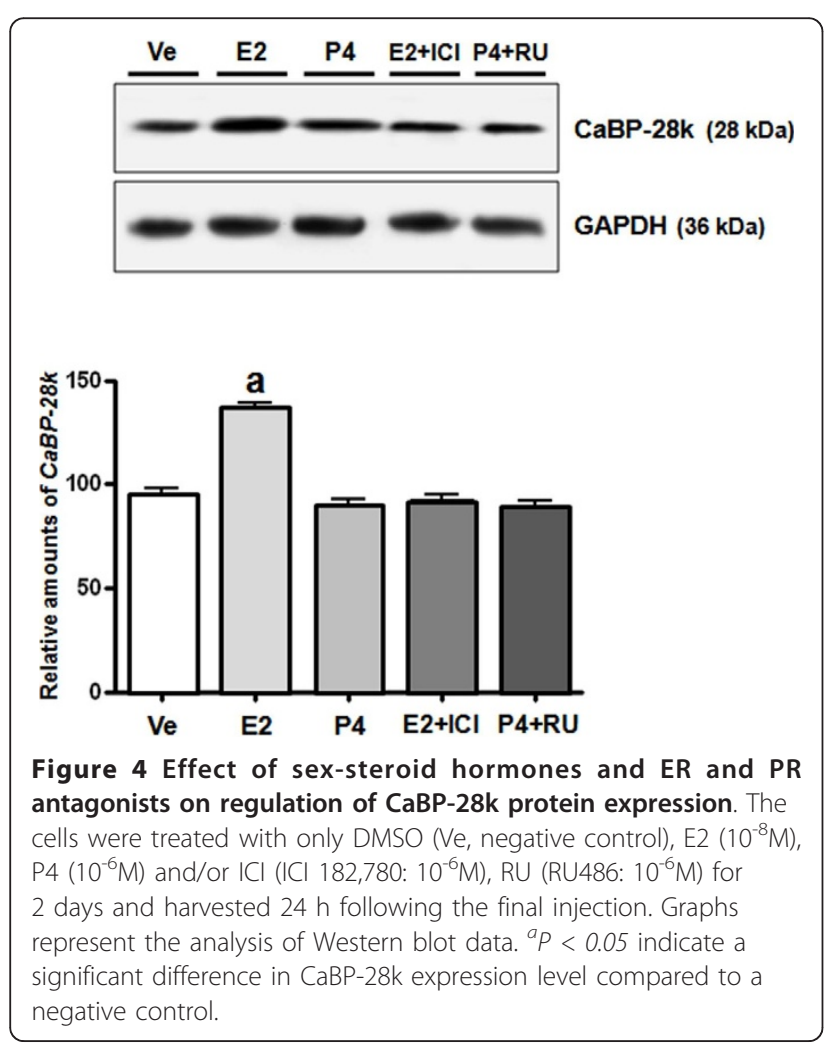

Endometrial CaBP-28k was highly expressed in cytoplasm of endometrial epithelial cells in early-, mid-, lateproliferative phase compared to secretory phases. Additionally, in the early-secretory phase, CaBP-28k was weakly expressed in the endometrial epithelial cells as compared to the glandular epithelial cells (Figure 5).

\section{Discussion}

We have previously determined that calcium-related proteins are regulated by sex-steroid hormones in the uterus of rodents $[26,31,36,37]$. It is well known that the status of the uterine cavity is important for successful implantation and is influenced by the secretory activity of the glandular epithelium [15,38,39]. In this study, CaBP-28k mRNA and protein were expressed in human endometrial tissues. The levels of calcium-related proteins fluctuated in E2-predominant stages [20,26,37]. CaBP-28k mRNA and protein were expressed at these stages [proliferative (early, mid, late) and secretory (only early) phase], followed by a decline in the secretory phase (mid-, late-) of the human endometrium, as demonstrated in this study. This result is in agreement with the pattern of CaBP-28k expression in the uterus of both mice and humans [28]. Therefore, these results indicate that this parallel pattern of CaBP-28k expression may be also involved in fetal implantation in humans.

Moreover, the level of CaBP-28k mRNA was increased by $\mathrm{E} 2\left(\mathrm{E}_{2}, 10^{-9} \mathrm{M}\right.$ to $\left.10^{-7} \mathrm{M}\right)$ in human endometrial cancer cells (Ishikawa cells) as shown in this study. Sexsteroid hormones can induce changes in the structure and function of the uterus and regulate menstrual cycle progression. To examine the effect of these hormones on uterine $\mathrm{CaBP}-28 \mathrm{k}$ expression, we treated Ishikawa cells with E2 $\left(10^{-8} \mathrm{M}\right)$ or P4 $\left(10^{-6} \mathrm{M}\right)$. Treatment with E2 resulted in increased uterine expression of CaBP-28k mRNA and protein, while P4 did not alter CaBP-28k expression. The expression of several calcium-related proteins is altered in an E2-dependent [31,37] or P4dependent $[26,36]$ manner in the estrus cycle. It is particularly interesting that calcium-related proteins are expressed during the estrus cycle, due to the wide variation in regulation of calcium-related protein expression in the uterus across species. Calcium-related proteins, which are crucial for early implantation, are also expressed in the endometrial layer [27,28,39]. However, it is still unclear why the uterine luminal epithelium increases $\mathrm{Ca}^{2+}$ uptake during implantation. In what aspect would this uptake facilitate blastocyst attachment at implantation? It is known that, for proper blastocyst implantation in human and mice, there must be interaction between adhesion-competent trophoblast cells and endometrial extracellular matrix components. The accumulation of integrin receptors for fibronectin on the 


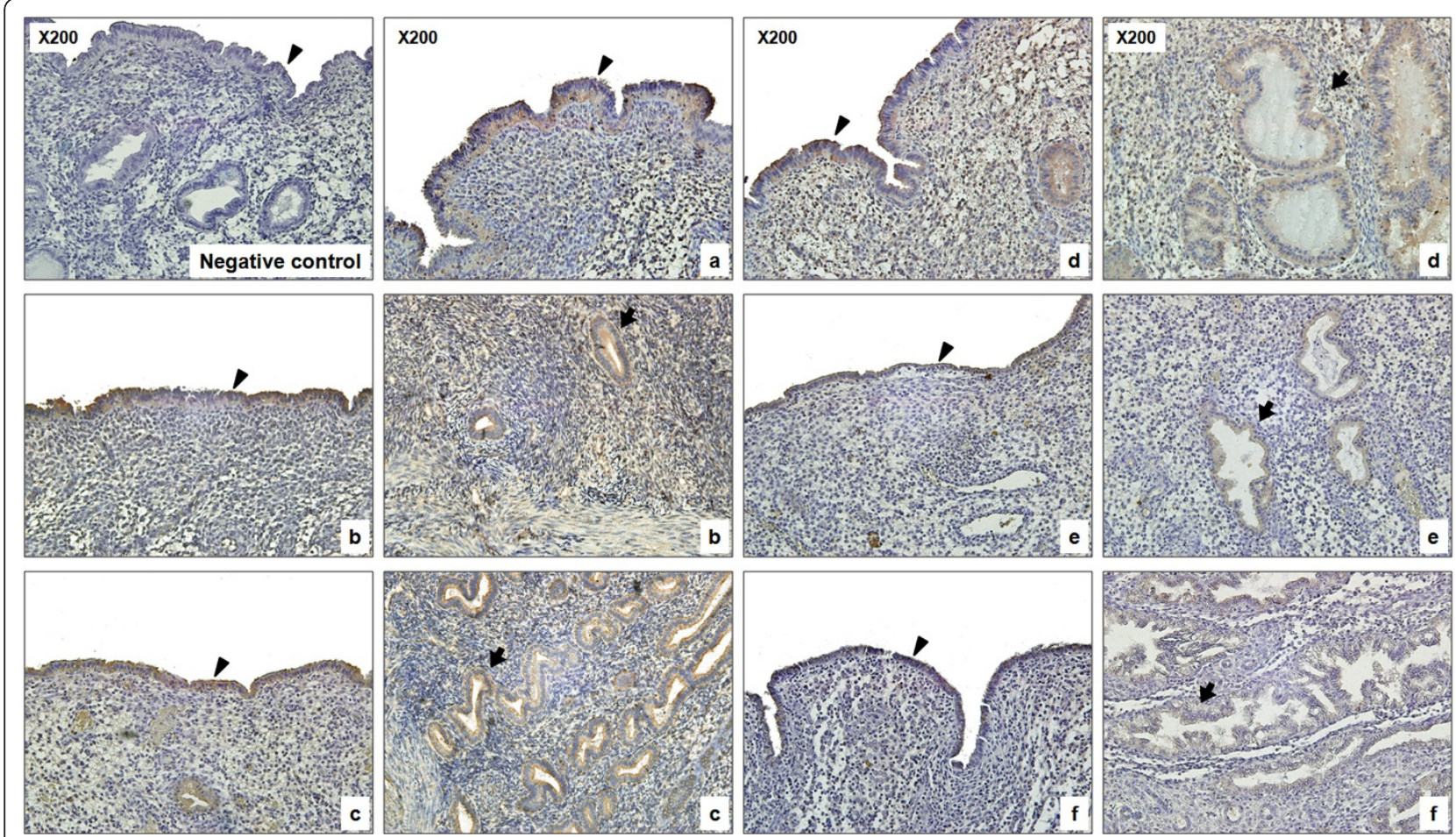

Figure $\mathbf{5}$ Localization of CaBP-28k protein in the human endometrium. Immunohistochemistry was performed to detect CaBP-28k protein in different phases in the uterine sections during the menstrual cycle ( $a$, early-proliferative phase; $b$, mid-proliferative phase; $c$, late-proliferative phase; d, early-secretory phase; e, mid-secretory phase; f, late-secretory phase) as described in Materials and Methods. Arrowheads $\rightarrow$ endometrial epithelial cells, arrows $\rightarrow$ endometrial glandular cells. Arrows and arrowheads indicate CaBP-28k-positive regions.

blastocyst surface enables it to bind to and penetrate the extracellular matrix (ECM) [40], but only when the blastocyst has reached an adhesion-competent state. Recently, it has been shown that the development of an adhesion-competent embryo is facilitated by heparinbinding epidermal growth factor (EGF)-like growth factor (HB-EGF) and that this process is dependent on calcium influx from extracellular sources [41]. The uterine epithelium is a barrier to interstitial blastocyst implantation, and it is also an important participant in the maternal-embryonic dialogue. During the periimplantation period, uterine epithelial cells produce HB-EGF [42] and the uterine glands secrete calcitonin [43], two paracrine or juxtacrine agents that are each capable of accelerating blastocyst differentiation. It is intriguing that the biological activity of both factors is dependent on $\mathrm{Ca}^{2+}$ signaling [44], which appears to regulate preimplantation embryogenesis beginning as early as the maturing oocyte $[45,46]$. These data suggest that a possible source of this external calcium needed for HBEGF-mediated differentiation of the blastocyst to an adhesion-competent state is from stores in the luminal epithelium of the endometrium.

As previously shown, the initial up-regulation of CaBP-28k increases the storage capacity for $\mathrm{Ca}^{2+}$ in luminal epithelial cells, and the subsequent specific down-regulation leads to an increase in free $\mathrm{Ca}^{2+}$ concentration [28]. In mammalian enterocytes, free $\mathrm{Ca}^{2+}$ ions are bound to cytosolic CaBP-9k and transferred across the cells by facilitated diffusion [47]. This transport of $\mathrm{Ca}^{2+}$ by CaBP-9k helps to maintain homeostasis by keeping intracellular $\mathrm{Ca}^{2+}$ ion concentrations below $10^{-7} \mathrm{M}$, preventing premature cell death by apoptosis. Thus, it can be speculated that the role of CaBP-28k protein in the uterine luminal epithelium is also to enhance $\mathrm{Ca}^{2+}$ uptake by increasing the cell-buffering capacity and stimulating the calcium entry mechanism in these cells. This release may trigger apoptosis in these specific epithelial cells because high concentrations of free $\mathrm{Ca}^{2+}$ are reported to cause apoptosis in many different cell types [48] and CaBP-28k is able to inhibit apoptosis in osteoblastic cells [49]. This apoptosis could, in turn, destabilize the epithelial barrier at the implantation site and facilitate trophoblast invasion and implantation.

An immunohistochemistry study revealed that the CaBP-28k protein was highly expressed in the cytoplasm of endometrial epithelial cells in the early-, mid-, lateproliferative compared with other phases, however, it was weakly expressed in endometrial epithelial cells as 
compared to that in glandular epithelial cells in the early-secretory phase. In the previous study, it was particularly interesting to observe that the regions where the uterine epithelium surrounded the implanting embryo were negative for CaBP-9k mRNA, whereas uniform expression was detected in the entire luminal epithelium in the regions where no embryo was attached [19]. Although CaBP-9k expression is not detected in human endometrium, either of CaBP-9k or CaBP-28k expression appears to be sufficient to facilitate implantation in mice [27]. We did not examine expression pattern(s) of $\mathrm{CaBP}-28 \mathrm{k}$ in the human uterus during pregnancy, partly because it is difficult to collect uterine samples from pregnant subjects due to ethical issues. Although we established that CaBP-28k expression occurred only during the menstrual cycle, we hypothesized that uterine CaBP-28k may be effectively mediated through maternal-fetal dialogue despite species differences between human and rodents. Thus, we assumed that CaBP-28k expression may be involved in endometrial receptivity during the menstrual cycle in humans.

\section{Acknowledgements}

This work was supported by the National Research Foundation of Korea (NRF) grant funded by the Korea government (MEST) (No. 2010-0011433).

\section{Author details}

${ }^{1}$ Laboratory of Veterinary Biochemistry and Molecular Biology, College of Veterinary Medicine, Chungbuk National University, Cheongju, Chungbuk 361-763, Republic of Korea. 'Department of Obstetrics and Gynecology, College of Medicine, Soonchunhyang University, Bucheon 420-767, Republic of Korea. ${ }^{3}$ Department of Preventive Medicine, College of Medicine, ChungAng University, Seoul 156-756, Republic of Korea. ${ }^{4}$ Department of Obstetrics and Gynecology, Faculty of Medicine, University of British Columbia, Vancouver, British Columbia, Canada.

\section{Authors' contributions}

HY and TK carried out the overall experiments including molecular experiments. TK, HL and $\mathrm{YH}$ provided human endometrial tissues and planed clinical experiments. KC participated in the real-time PCR and immunohistochemical analysis. PL participated in the design of the study, performed the statistical analysis and helped to finalize the manuscript. EJ* designed and coordinated the overall study as a corresponding author and helped to draft the manuscript. All authors read and approved the final manuscript.

\section{Competing interests}

The authors declare that they have no competing interests.

Received: 3 December 2010 Accepted: 2 March 2011 Published: 2 March 2011

\section{References}

1. Opperman LA, Saunders TJ, Bruns DE, Boyd JC, Mills SE, Bruns ME: Estrogen inhibits calbindin-D28k expression in mouse uterus. Endocrinology 1992, 130(3):1728-1735.

2. L'Horset F, Blin C, Brehier A, Thomasset M, Perret C: Estrogen-induced calbindin-D 9k gene expression in the rat uterus during the estrous cycle: late antagonistic effect of progesterone. Endocrinology 1993, 132(2):489-495.

3. Wasserman RH, Fullmer CS: Calcium transport proteins, calcium absorption, and vitamin D. Annu Rev Physiol 1983, 45:375-390.
4. Manolagas SC, Provvedini DM, Murray EJ, Murray SS, Tsonis PA, Spandidos DA: Association between the expression of the c-myc oncogene mRNA and the expression of the receptor protein for 1,25dihydroxyvitamin D3. Proc Natl Acad Sci USA 1987, 84(3):856-860.

5. Manolagas SC, Hustmyer FG, Yu XP: 1,25-Dihydroxyvitamin D3 and the immune system. Proc Soc Exp Biol Med 1989, 191(3):238-245.

6. Mathew PA, Ellis LK, Studzinski GP: Enhanced messenger RNA stability and differentiation of HL 60 cells treated with 1,25-dihydroxyvitamin D3 and cordycepin. J Cell Physiol 1989, 140(2):212-218.

7. Reichel H, Koeffler HP, Norman AW: The role of the vitamin D endocrine system in health and disease. N Engl J Med 1989, 320(15):980-991.

8. Simpson RU, Weishaar RE: Involvement of 1,25-dihydroxyvitamin D3 in regulating myocardial calcium metabolism: physiological and pathological actions. Cell Calcium 1988, 9(5-6):285-292.

9. Kwiecinski GG, Petrie Gl, DeLuca HF: Vitamin D is necessary for reproductive functions of the male rat. J Nutr 1989, 119(5):741-744.

10. Halloran BP, DeLuca HF: Vitamin D deficiency and reproduction in rats. Science 1979, 204(4388):73-74.

11. Halloran BP, DeLuca HF: Effect of vitamin D deficiency on fertility and reproductive capacity in the female rat. J Nutr 1980, 110(8):1573-1580.

12. Mathieu CL, Burnett SH, Mills SE, Overpeck JG, Bruns DE, Bruns ME: Gestational changes in calbindin-D9k in rat uterus, yolk sac, and placenta: implications for maternal-fetal calcium transport and uterine muscle function. Proc Natl Acad Sci USA 1989, 86(9):3433-3437.

13. Warembourg $M$, Perret $C$, Thomasset $M$ : Analysis and in situ detection of cholecalcin messenger RNA ( $9000 \mathrm{Mr}$ CaBP) in the uterus of the pregnant rat. Cell Tissue Res 1987, 247(1):51-57.

14. Delorme AC, Danan JL, Acker MG, Ripoche MA, Mathieu H: In rat uterus 17 beta-estradiol stimulates a calcium-binding protein similar to the duodenal vitamin D-dependent calcium-binding protein. Endocrinology 1983, 113(4):1340-1347.

15. Nys $Y$, Mayel-Afshar $S$, Bouillon $R$, Van Baelen $H$, Lawson DE: Increases in calbindin D 28K mRNA in the uterus of the domestic fowl induced by sexual maturity and shell formation. Gen Comp Endocrinol 1989, 76(2):322-329.

16. Corradino RA, Wasserman RH, Pubols MH, Chang SI: Vitamin D3 induction of a calcium-binding protein in the uterus of the laying hen. Arch Biochem Biophys 1968, 125(1):378-380.

17. Bruns ME, Overpeck JG, Smith GC, Hirsch GN, Mills SE, Bruns DE: Vitamin Ddependent calcium binding protein in rat uterus: differential effects of estrogen, tamoxifen, progesterone, and pregnancy on accumulation and cellular localization. Endocrinology 1988, 122(6):2371-2378.

18. Jung YW, Hong EJ, Choi KC, Jeung EB: Novel progestogenic activity of environmental endocrine disruptors in the upregulation of calbindinD9k in an immature mouse model. Toxicol Sci 2005, 83(1):78-88.

19. Nie GY, Li Y, Wang J, Minoura H, Findlay JK, Salamonsen LA: Complex regulation of calcium-binding protein $\mathrm{D} 9 \mathrm{k}$ (calbindin-D(9k)) in the mouse uterus during early pregnancy and at the site of embryo implantation. Biol Reprod 2000, 62(1):27-36.

20. Krisinger J, Dann JL, Currie WD, Jeung EB, Leung PC: Calbindin-D9k mRNA is tightly regulated during the estrous cycle in the rat uterus. Mol Cell Endocrinol 1992, 86(1-2):119-123.

21. Psychoyos A: Hormonal control of ovoimplantation. Vitam Horm 1973, 31:201-256.

22. Carson DD, Bagchi I, Dey SK, Enders AC, Fazleabas AT, Lessey BA, Yoshinaga K: Embryo implantation. Dev Biol 2000, 223(2):217-237.

23. Schlafke $S$, Enders AC: Cellular basis of interaction between trophoblast and uterus at implantation. Biol Reprod 1975, 12(1):41-65.

24. Yoshinaga K: Uterine receptivity for blastocyst implantation. Ann N Y Acad Sci 1988, 541:424-431.

25. Sharkey A: Cytokines and implantation. Rev Reprod 1998, 3(1):52-61.

26. Lee GS, Jeung EB: Uterine TRPV6 expression during the estrous cycle and pregnancy in a mouse model. Am J Physiol Endocrinol Metab 2007, 293(1): E132-138.

27. Luu KC, Nie GY, Hampton A, Fu GQ, Liu YX, Salamonsen LA: Endometrial expression of calbindin ( $\mathrm{CaBP}$ )-d28k but not $\mathrm{CaBP}-\mathrm{d} 9 \mathrm{k}$ in primates implies evolutionary changes and functional redundancy of calbindins at implantation. Reproduction 2004, 128(4):433-441.

28. Luu KC, Nie GY, Salamonsen LA: Endometrial calbindins are critical for embryo implantation: evidence from in vivo use of morpholino antisense oligonucleotides. Proc Natl Acad Sci USA 2004, 101(21):8028-8033. 
29. Aneiros E, Philipp S, Lis A, Freichel M, Cavalie A: Modulation of Ca2+ signaling by $\mathrm{Na}+/ \mathrm{Ca} 2+$ exchangers in mast cells. J Immunol 2005, 174(1):119-130.

30. Kiedrowski L: High activity of K+-dependent plasmalemmal $\mathrm{Na}+/ \mathrm{Ca} 2+$ exchangers in hippocampal CA1 neurons. Neuroreport 2004, 15(13):2113-2116.

31. Hong EJ, Choi KC, Jeung EB: Induction of calbindin-D9k messenger RNA and protein by maternal exposure to alkylphenols during late pregnancy in maternal and neonatal uteri of rats. Biol Reprod 2004, 71(2):669-675.

32. Noyes RW, Hertig AT, Rock J: Dating the endometrial biopsy. Am J Obstet Gynecol 1975, 122(2):262-263.

33. Dang VH, Nguyen $T H$, Choi $K C$, Jeung EB: A calcium-binding protein, calbindin-D9k, is regulated through an estrogen-receptor mediated mechanism following xenoestrogen exposure in the GH3 cell line. Toxicol Sci 2007, 98(2):408-415.

34. Tatsumi K, Higuchi T, Fujiwara H, Nakayama T, Itoh K, Mori T, Fujii S, Fujita J: Expression of calcium binding protein D-9k messenger RNA in the mouse uterine endometrium during implantation. Mol Hum Reprod 1999, 5(2):153-161.

35. Tinnanooru P, Dang VH, Nguyen TH, Lee GS, Choi KC, Jeung EB: Estrogen regulates the localization and expression of calbindin-D9k in the pituitary gland of immature male rats via the ERalpha-pathway. Mol Cell Endocrinol 2008, 285(1-2):26-33.

36. Kim HJ, Lee GS, Ji YK, Choi KC, Jeung EB: Differential expression of uterine calcium transporter 1 and plasma membrane Ca2+ ATPase $1 \mathrm{~b}$ during rat estrous cycle. Am J Physiol Endocrinol Metab 2006, 291(2):E234-241.

37. Yang H, Lee GS, Yoo YM, Choi KC, Jeung EB: Sodium/potassium/calcium exchanger 3 is regulated by the steroid hormones estrogen and progesterone in the uterus of mice during the estrous cycle. Biochem Biophys Res Commun 2009, 385(2):279-283.

38. Cai L, Zhang J, Duan E: Dynamic distribution of epidermal growth factor during mouse embryo peri-implantation. Cytokine 2003, 23(6):170-178

39. Salamonsen LA, Nie G, Dimitriadis E, Robb L, Findlay JK: Genes involved in implantation. Reprod Fertil Dev 2001, 13(1):41-49.

40. Wang J, Mayernik L, Armant DR: Integrin signaling regulates blastocyst adhesion to fibronectin at implantation: intracellular calcium transients and vesicle trafficking in primary trophoblast cells. Dev Biol 2002, 245(2):270-279.

41. Wang J, Mayernik L, Schultz JF, Armant DR: Acceleration of trophoblast differentiation by heparin-binding EGF-like growth factor is dependent on the stage-specific activation of calcium influx by ErbB receptors in developing mouse blastocysts. Development 2000, 127(1):33-44.

42. Das SK, Wang XN, Paria BC, Damm D, Abraham JA, Klagsbrun M, Andrews GK, Dey SK: Heparin-binding EGF-like growth factor gene is induced in the mouse uterus temporally by the blastocyst solely at the site of its apposition: a possible ligand for interaction with blastocyst EGF-receptor in implantation. Development 1994, 120(5):1071-1083.

43. Ding YQ, Zhu $L$, Bagchi MK, Bagchi IC: Progesterone stimulates calcitonin gene expression in the uterus during implantation. Endocrinology 1994, 135(5):2265-2274.

44. Wang J, Rout UK, Bagchi IC, Armant DR: Expression of calcitonin receptors in mouse preimplantation embryos and their function in the regulation of blastocyst differentiation by calcitonin. Development 1998, 125(21):4293-4302.

45. Leach RE, Stachecki JJ, Armant DR: Development of in vitro fertilized mouse embryos exposed to ethanol during the preimplantation period: accelerated embryogenesis at subtoxic levels. Teratology 1993, 47(1):57-64

46. Kono T, Jones KT, Bos-Mikich A, Whittingham DG, Carroll J: A cell cycleassociated change in $\mathrm{Ca} 2+$ releasing activity leads to the generation of $\mathrm{Ca} 2+$ transients in mouse embryos during the first mitotic division. J Cell Biol 1996, 132(5):915-923.

47. Walters JR: Calbindin-D9k stimulates the calcium pump in rat enterocyte basolateral membranes. Am J Physiol 1989, 256(1 Pt 1):G124-128.

48. Tombal B, Denmeade SR, Gillis JM, Isaacs JT: A supramicromolar elevation of intracellular free calcium $([\mathrm{Ca}(2+)](\mathrm{i}))$ is consistently required to induce the execution phase of apoptosis. Cell Death Differ 2002, 9(5):561-573.
49. Bellido T, Huening M, Raval-Pandya M, Manolagas SC, Christakos S: Calbindin-D28k is expressed in osteoblastic cells and suppresses their apoptosis by inhibiting caspase-3 activity. J Biol Chem 2000, 275(34):26328-26332.

doi:10.1186/1477-7827-9-28

Cite this article as: Yang et al:: Expression of calbindin-D28k and its regulation by estrogen in the human endometrium during the menstrual cycle. Reproductive Biology and Endocrinology 2011 9:28.

\section{Submit your next manuscript to BioMed Central and take full advantage of:}

- Convenient online submission

- Thorough peer review

- No space constraints or color figure charges

- Immediate publication on acceptance

- Inclusion in PubMed, CAS, Scopus and Google Scholar

- Research which is freely available for redistribution

Submit your manuscript at www.biomedcentral.com/submit 